\author{
Katarzyna Wojtanowicz \\ Uniwersytet Papieski Jana Pawła II w Krakowie \\ Mateusz Pękala \\ Akademia Ignatianum w Krakowie
}

\title{
Międzynarodowy DZień Mediacji 2018 SPRAWOZDANIE Z SYMPOZJUM
}

Sprawozdanie z sympozjum Międzynarodowy Dzień Mediacji 2018, Kraków, 17 października 2018 roku.

Dwie krakowskie uczelnie: Uniwersytet Papieski Jana Pawła II w Krakowie oraz Akademia Ignatianum w dniu 17 października 2018 roku wspólnie zorganizowały obchody Międzynarodowego Dnia Mediacji. Jest to coroczne wydarzenie o charakterze ogólnopolskim, nad którym patronat sprawuje Ministerstwo Sprawiedliwości. Mediacja w Polsce powoli zdobywa swoje uznanie i powszechność stosowania, stąd każde wydarzenie promujące metody polubowne przyczynia się do wzmacniania społecznych postaw nastawionych na podjęcie dialogu i współpracy.

W tym dniu organizatorzy przygotowali sympozjum z udziałem badaczy i osób uprawiających zawód mediatora. Spotkanie rozpoczęły warsztaty dla początkujących, w tym dla studentów naszych uczelni, które poprowadził dr Mateusz Pękala z Akademii Ignatianum. Uczestnicy tej części spotkania mogli spróbować przeanalizować i zrozumieć sytuacje konfliktowe, co stanowi pierwszy krok do podjęcia działań w kierunku koncyliacyjnego rozwiązania sytuacji spornej.

W głównej części spotkania uczestnicy wysłuchali wystąpień czterech prelegentów. Wykład wprowadzający wygłosił mgr Konrad Sobczyk, prezes Stowarzyszenia Mediatorów Rodzinnych oraz członek Społecznej Rady do spraw Alternatywnych Metod Rozwiązywania Sporów przy Ministrze Sprawiedliwości. Pan Sobczyk bardzo ciekawie zbudował most pomiędzy historią mediacji w Polsce a jej przyszłością. Wskazał na rosnące statystyki zastosowania mediacji oraz kierunki jej rozwoju. Nawiązał również 
do zmian legislacyjnych, które zachęcają z jednej strony do zastosowania mediacji, $\mathrm{z}$ drugiej natomiast omówił wzrost postaw, choć jeszcze ciągle wymagający podejmowania wszechstronnych działań, nastawionych na wykorzystanie alternatywnych metod rozwiązywania konfliktów w sferach społecznych i osobistych.

Następnie głos zabrała mgr Anna Cybulko z Uniwersytetu Warszawskiego, na którym pełni funkcję rzecznika akademickiego - Ombudsmana. Prelegentka podzieliła się swoim doświadczeniem pełnienia innowacyjnej jak na polskie warunki funkcji. Przedstawiła statystyki podejmowanych działań oraz bardzo szeroki obszar swojej działalności. Ombudsman to osoba niezależna i neutralna, do której mogą się zgłaszać studenci i pracownicy w sposób nieformalny i poufny z prośbą o pomoc w sprawach dotyczących uczelni i jej społeczności. Podejmuje on działania wspierające pracowników i studentów w rozwiązywaniu sytuacji konfliktowych oraz dba o sprawiedliwe i uczciwe traktowanie.

Kolejna prelegentka, dr Katarzyna Wojtanowicz z Uniwersytetu Papieskiego Jana Pawłą II w Krakowie, zaprezentowała praktykę wykorzystania mediacji w interwencji kryzysowej na przykładzie Ośrodka Interwencji Kryzysowej w Myślenicach. Prelegentka dokonała analizy porównawczej metodyki interwencji kryzysowej i mediacji, wskazując ich punkty wspólne. Omówiła również szerokie korzyści z zastosowania mediacji u osób przeżywających kryzysy. Mediacja w pracy OIK pełni ważną funkcję dopełniającą podejmowane oddziaływania wspierająco-terapeutyczne.

Spotkanie w tej części zakończył dr Mateusz Pękala z AIK, wystąpieniem na temat wykorzystania technik mediacyjnych w zarządzaniu organizacjami. Prelegent wskazał na rolę umiejętności mediacyjnych, negocjacyjnych oraz komunikacyjnych w skutecznym zarządzaniu. Uniwersalność mediacji oraz zastosowanie alternatywnych metod rozwiązywania sporów są ważnymi elementami budowania dojrzałości organizacji oraz jej lepszego funkcjonowania w sferze społecznej.

Trzecia część spotkania była przeznaczona dla czynnych zawodowo mediatorów, którym stworzono możliwość poddania praktyki mediacyjnej superwizji, którą poprowadził mgr Konrad Sobczyk.

Obchody Międzynarodowego Dnia Mediacji 2018 przyniosły bardzo wymierne korzyści. Przede wszystkim były ważnym głosem w dyskusji nad zastosowaniem mediacji w Polsce oraz jej promocją. Wydarzenie to zacieśniło również współpracę pomiędzy Uniwersytetem Papieskim Jana Pawła II w Krakowie a Akademią Ignatianum, która jest kontynuowana. W ramach Małopolskiego Klubu Pracownika Socjalnego funkcjonującego w Instytucie Pracy Socjalnej WNS UPJPII utworzono sekcję mediatorów, której celem jest organizacja cyklicznych spotkań edukacyjnych i wspierających dla mediatorów oraz integracja środowiska mediacyjnego. 